\title{
An Analysis of Students Error on Inversely Proportional Question at Grade VIII F SMP Negeri 9 Palu
}

\author{
Anggraini $^{1}$, Pathuddin ${ }^{2 *}$, Israni Sande ${ }^{2}$, Mustamin Idris ${ }^{2}$ \\ ${ }^{1,2}$ Mathematics Education Study Program, Teacher Training and Education Faculty, Tadulako University, 94118, Palu, Indonesia \\ *pathuddin@yahoo.com
}

\begin{abstract}
The purpose of this study was to describe the students error on inversely proportional question at grade VIII F SMP Negeri 9 Palu. This type of research is qualitative research. Data were collected using data collection techniques, namely tests and interviews. The research subjects consisted of 3 people, namely C students, HD students and YYA students. The results of the study based on the students completion showed the mistakes made by the students in solving the comparison questions against the scores that were done. Based on the solution, conceptual and procedural errors were obtained. Conceptual errors include: a) factual errors consisting of: 1) students have not been able to write down the information contained in the questions, 2) students have not been able to understand the use of the equal sign correctly, 3) students have not been able to change the information contained in the questions into a model mathematics and 4) students have not been able to write conclusions correctly. b) Misconceptions consist of: 1) students do not understand the concept of reversing value comparisons, namely students working on comparison questions of turning values using the principle of value comparisons, 2) students have not been able to operate a reversed value comparison and 3) students do not understand the concept of multiplication and division of integers and decimal numbers. Procedural errors consist of: 1) students have not been able to work on questions using the principle of reversing value comparisons, 2) students make mistakes operating multiplication and division and 3) students have not been able to determine the final result correctly.
\end{abstract}

Keywords

Error analysis, conceptual and procedural errors, inversely proportional question

\section{Introduction}

Mathematics is a universal science that has a major role in developments in science, technology and information. Mathematics lessons are given at every level of education in schools with the aim of developing logical, analytical, systematic, critical and creative thinking skills as well as students ability to work together.

The ability to solve problems is one of the important aspects to be developed in mathematics learning in schools because it is in line with the essence of the purpose of education in Indonesia, which is a continuous process to overcome problems faced throughout life. Problem solving skills are very important in mathematics, not only for those who will later explore or study mathematics, but also for those who will apply it in other fields of study and in everyday life [1]. For this reason, humans need to be trained to think independently through problem solving based learning [2]. Poblem solving abilities are important to be developed in schools because generally what is learned in mathematics learning is problem solving strategies and in certain cases it can be transferred and applied in other problem solving situations [3]. In addition, solving problems mathematically can help students improve their analytical abilities and can help them apply these abilities to various situations. Realizing the importance of the ability to solve mathematical problems in life, students need to master it well in order to use it in everyday life.

Efforts to improve the quality of education are not only the task of the government but also the task of the community, teachers and parties related to education. There have been many attempts by the government to improve the quality of education in Indonesia, including by adjusting the curriculum and equalizing teachers, but the results have not been maximal and are classified as low, especially mathematics learning outcomes.

The low student learning outcomes can be seen from the low average national exam scores in mathematics. Based on the national exam results report for the 2017/2018 academic year by the education research center of the Ministry of Education and Culture, the national average score of the national junior high school mathematics exam results is 43.34. This can be seen from the students mastery of the material. Mastery of the material can be measured using the questions given. After giving the test questions, the teacher can see the mistakes made by students based on the completion of the questions that the students did. These mistakes can provide clues to the extent of knowledge that students have.

Comparative material is one of the materials taught at the junior high school level. The subject taught is the comparison of turning values. Based on the results of interviews with mathematics subject teachers at SMP Negeri 9 Palu, information was obtained that from the material that was sent, the average student made errors in the comparison material turned around in value. According to the teacher, the comparative material is one of the materials that students do not understand and mistakes often occur in solving story questions even during national exams. The mistakes made by students in solving story problems, among others; students do not understand the problem of the problem so it is difficult to write down the information contained in the 
questions, students find it difficult to distinguish between value comparison story questions with a value reversal comparison, and errors in solving comparison story questions turn around scores that are solved with a value comparison. In addition to these errors, there are also errors in manipulating algebraic operations, errors in drawing conclusions, students only rely on sample questions given by the teacher, and errors do not work on the questions. The mistakes made by students above include conceptual errors and procedural errors. This can happen because in the learning process the teacher uses mathematics textbook teaching materials provided in schools without designing their own comparison topics to be taught.

The low math ability of students is influenced by many factors. These factors come from within and from outside the student. Factors from within students can be in the form of intellectual abilities, motivation, interests, talents and others. While factors from outside students can be influenced by environmental conditions, family, teachers, friends, learning tools and others [4].

Teachers tend to present lessons in accordance with the flow provided by the book. The material in the book is presented directly on the concept without the process of involving students in discovery in order to build concepts on the material being studied. In learning, the teacher teaches the material on the comparison of turning values along with examples so that students can understand the material being taught. After teaching the material, the teacher assigns assignments to students to solve comparative story problems turning scores. The students worked on the story questions. The results of student work are then checked by the teacher and distributed to students after they have been examined. The examples and exercises presented only aim to practice numeracy skills and use formulas and result in students not being accustomed to using reasoning skills in solving a problem. Without good and correct reasoning in understanding problems, it is difficult for students to plan problem solving, let alone solve them correctly. This resulted in mathematics learning not yet running effectively and not on target.

Proving the truth that there were mistakes made by students based on problem solving, the researcher conducted an identification test regarding the comparison of turning scores to class VIII F SMP Negeri 9 Palu who had participated in learning about the comparison of reversing grades.

From the results of student work it is necessary to carry out a completion analysis so that it can provide information about the mistakes made by students. A detailed student completion analysis is necessary so that the mistakes made by students and the causes of these errors can be identified so as to help overcome the errors experienced and improve student achievement. Researchers analyzed student completion referring to mathematical objects in order to obtain errors consisting of errors in facts, concepts, principles and skills.

Based on the above background, the researcher is interested in conducting a research entitled "An Analysis of Students Error on Inversely Proportional Question at Grade VIII F SMP Negeri 9 Palu“"

\section{Method}

The purpose of this study was to describe the mistakes made by students in solving the reverse comparison story problem, so this research is a descriptive study with a qualitative approach. The subjects in this study were taken from class VIII F students of SMP Negeri 9 Palu in the 2019/2020 school year who were selected based on teacher recommendations. Subjects selected as informants were 3 students out of 32 students based on the following considerations: 1) errors made by students at most, 2) errors varied and different from other students, 3) student errors represented errors made by other students, 4) ability students in communicating and 5) recommendation from mathematics teachers at SMP Negeri 9 Palu.

The instrument in this study was a story question related to the material inversely proportional question and interview guidelines. Story questions are used to determine the types of errors made by students, while the interview guidelines are used as guidelines for conducting interviews with subjects to be studied with the aim of clarifying the written test answers that have been given and to explore data that are not revealed from the results of written test answers regarding the types of errors made by the subject in solving comparative story problems turned around in value. The researcher gave a test in the form of a story question to the students related to the comparative material turning scores to get the subject then corrected the students written answers based on the type of error indicator set by the researcher. The technique of checking the validity of the data used is time triangulation. The researcher gave a story question test related to the comparison material turning around the equivalent of a story question test related to the comparison material turning around values at different times to check the credibility of the research data. Time triangulation was conducted to find the suitability of the test and interview result data. Data analysis refers to the model of Miles and Huberman [5], namely data reduction, data presentation and conclusion drawing.

\section{Results}

The subjects of this study were students of class VIII F SMP Negeri 9 Palu which consisted of 32 students. Students are given a test of 2 items on the comparison material of turning the value as follow:

1. A car traveling the distance from city A to city B using the toll road takes 1,2 hours with an average speed of $80 \mathrm{~km} / \mathrm{hour}$. So that the distance can be covered in 60 minutes, what is the average speed of the car?

2. A packet of chocolate candies containing several chocolates will be distributed to 9 childrens, each child gets 4 chocolates. If the chocolates were distributed among 12 childrens, how much chocolate would each child get?

The description of student problem solving in solving problems on the comparison material turns the value on each question as follow:

1. Student Completion Analysis C 
a) Analysis of completion in question number 1

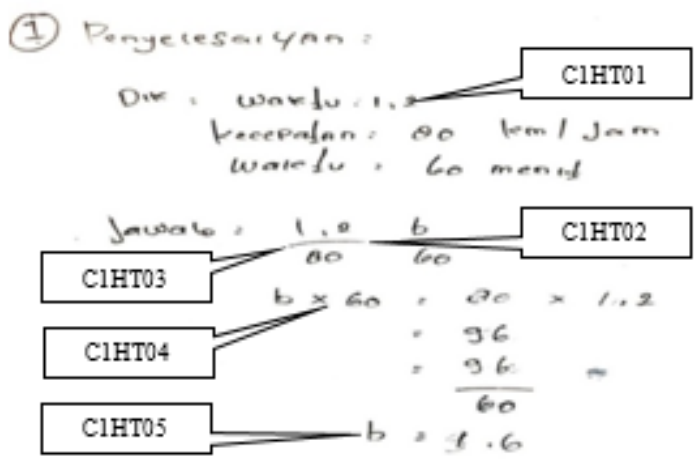

Figure 1. C students answer to question number 1

Based on the results of the analysis of the students completion, it is illustrated that students have not been able to define the ratio of turning points well. In addition, students have not been careful in using units, especially in different units of time as written by students, namely time $=$ 1,2 (CIHT01). This description shows that there is a fact error caused by the fact that students have not been able to connect the existing units, namely the time unit for 1,2 and 60 minutes. Furthermore, students have not been able to use the equal sign as they should be in writing the mathematical model as illustrated by the student's completion by writing $\frac{1,2}{80} \frac{b}{60}$ (C1HT02). This also shows the fact that there is a fact error that is caused because students do not understand the use of the equal sign properly. In the completion section, it can be seen that students have not been careful in writing the information contained in the questions into a mathematical model as illustrated by the student's completion, namely by writing $\frac{1,2}{80} \quad \frac{b}{60}$ (C1HT03). This description shows that there was a misconception that was made because students did not understand what to compare in the question. In this section, students write a ratio of $\frac{1,2}{80}$ where 1,2 is the time and 80 is the velocity and compares $\frac{b}{60}$ where $b$ is what is asked in the question and 60 is the time. In the operation section, students do not understand what to operate and how to operate the correct reversal value comparison so that there is an error in the student work procedure as illustrated by the student's completion, namely $b \times 60=80 \times 1,2$ (C1HT04) so that the final results obtained are also wrong, namely $b=1.6$ (C1HT05). Furthermore, students did not write down the conclusions of the questions so that there were fact errors made by students because students did not understand in drawing conclusions.

b) Analysis of completion in question number 2

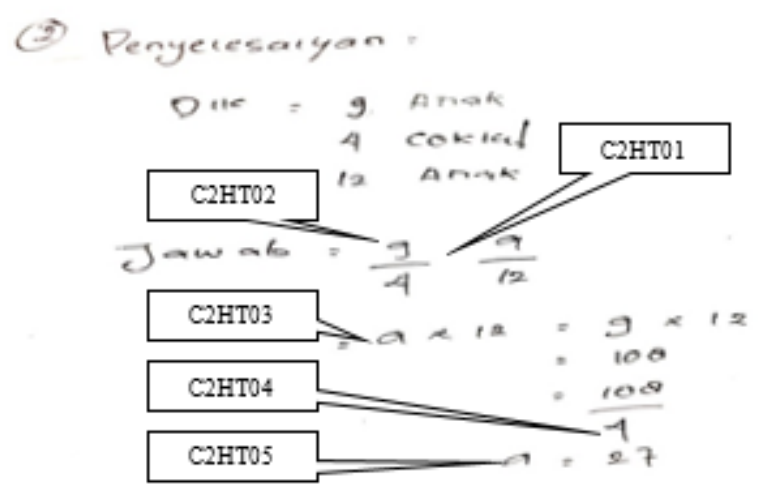

Figure 2. $\mathrm{C}$ students answer to question number 2

Based on the results of the analysis of students completion, it is illustrated that students have not been able to use the equal sign as they should in writing a mathematical model, namely by writing $\frac{9}{4} \frac{a}{12}$ (C2HT01). This shows that there is a fact that there is an error caused because students have not understood the correct use of the equal sign. In the settlement section, it can be seen that students have not been careful in writing the information contained in the questions into the mathematical model as illustrated by the student's completion by writing $\frac{9}{4} \frac{a}{12}$ (C2HT02). This description shows that there was a misconception that was made because students did not understand what to compare in the question. In this section, students write a ratio of $\frac{9}{4}$ where 9 is the number of children and 4 is the number of chocolates and compares $\frac{a}{12}$ where a is what is asked in the question and 12 is the number of children. Furthermore, students do not understand what to operate and how to operate the reversal value comparison correctly so that there are errors in student work procedures as illustrated by student completion, namely $a \times 12=9 \times 12$ (C2HT03). In addition, students have not been careful in operating the questions so there is a fact error where students write $\frac{180}{4}$ (C2HT04) on the right side while on the left side it is written $a \times 12$ so that the final result obtained is also wrong, namely $a=27$ (C2HT05). Furthermore, students did not write down the conclusions of the questions so that there were fact errors made by students because students did not understand in drawing conclusions.

2. HD Student Completion Analysis

a) Analysis of the completion of question number 1 


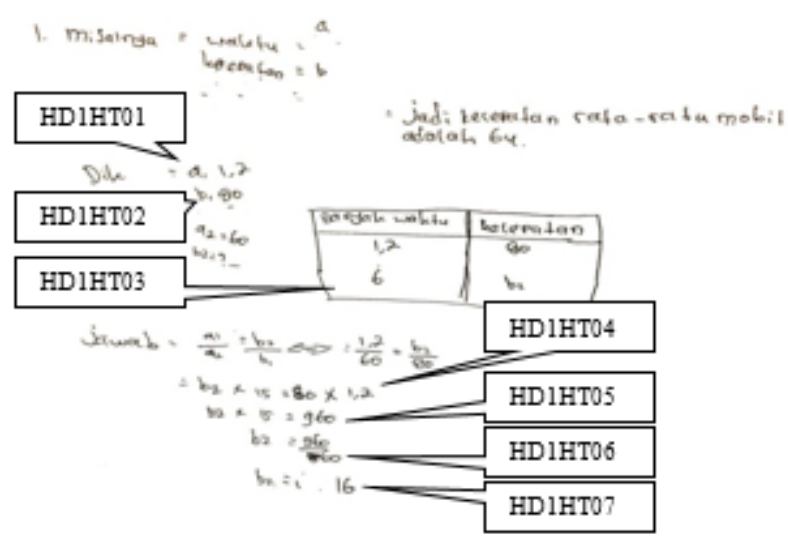

Figure 3. HD students answers to question number 1

Based on the results of the analysis of students' completion, it is illustrated that students have not been able to use the equal sign as they should be in writing what is known in the questions as found in $a_{1}$ and $b_{1}$ (HD1HT01). This description shows that there are fact errors caused because students have not understood the correct use of the equal sign. In addition, students have not been careful in the use of units, especially in the time and speed units found in $a_{1}, b_{1}$ and $a_{2}$ (HD1HT02). This shows that there is a fact error that is caused because students have not been able to understand the importance of using units when writing information on questions. Furthermore, students have not been careful in writing every information contained in the questions as illustrated in the table of times, namely by writing 1,2 and 6 (HD1HT03) while the information contained in the questions is 1,2 and 60 . In addition, students have not been careful in writing numbers when operating the comparison by writing $b_{2} \times 15=80 \times 1,2$ (HD1HT04). This shows that there are fact errors caused by students not being focused and not careful in writing down the information contained in the questions. Furthermore, students have not been able to operate the comparison correctly as illustrated by the students' completion by writing $b_{2} \times 15=960$ (HD1HT05), $b_{2}=\frac{960}{60}$ (HD1HT06) and the final result obtained is $b_{2}=16$ (HD1HT07). This description shows that there was a misconception because students did not understand the concept of multiplication and division of integers. In addition, there was a procedural error because students did not understand the principle of multiplication of whole numbers and decimal numbers.

\section{b) Solution analysis on question 2}

Based on the results of the analysis of the students' completion, it is illustrated that students have not been able to sort out the information contained in the questions (HD2HT01). This shows that there is a fact error that is caused because students have not been able to connect the information contained in the questions to the solution. In the known part, students have not been careful in using the equal sign and unit by writing $a_{1} 9, b_{1} 4$ and $a_{2} \quad 15$ (HD2HT02). This description shows that there is a fact error that is caused because students have not been able to connect the information contained in the questions into the mathematical model. In addition, students have not been careful in writing the densest information on $a_{2}$, namely by writing $a_{2} 15$ (HD2HT03) so that when operating the comparison, the final result is wrong, namely $b_{2}=2,4$ (HD2HT04). This description shows that there was a procedural error caused by the students not being careful in working on the questions.

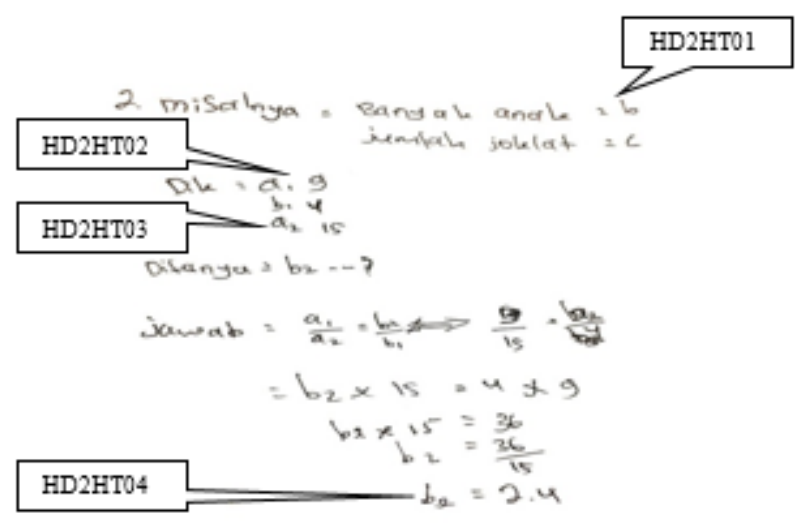

Figure 4. HD students answers to question number 2

3. Student Completion Analysis YYA

a) Analysis of completion in question number 1

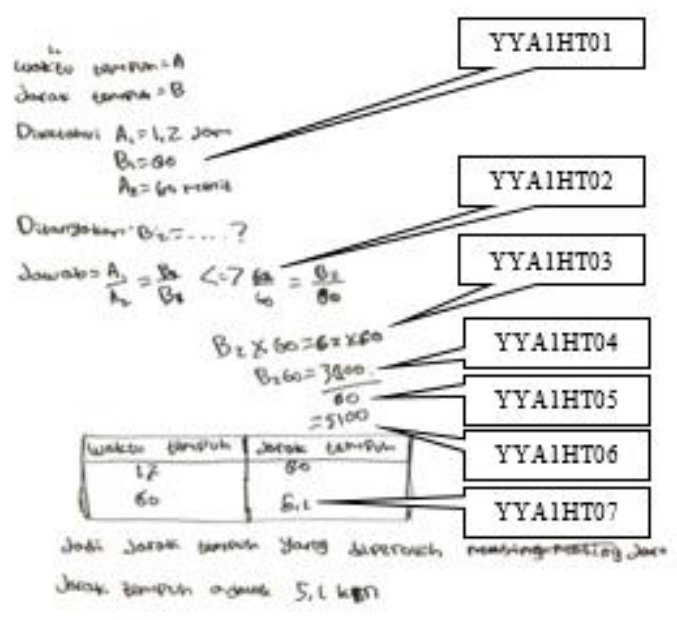

Figure 5. YYA students answers to question number 1

Based on the results of the analysis of the students' completion, it is illustrated that the students have not been able to define the ratio of turning points correctly. In addition, students have not been careful in using the speed unit as in the known part of the student writing $B_{1}=80$ (YYA1HT01) and using the time unit contained in $A_{1}$ correctly as in writing a mathematical model, namely 
$\frac{A_{1}}{A_{2}}=\frac{B_{2}}{B_{1}} \leftrightarrow \frac{62}{60}=\frac{B_{2}}{80} \quad$ (YYA1HT02). This description shows that there was a misconception because they were unable to relate the information contained in the questions to those being asked. Furthermore, students have not been careful in operating the correct reversal ratio as illustrated in the student's problem solving, namely $B_{2} \times 60=62 \times 60$ (YYA1HT03). This description shows that there was a procedural error caused by the fact that students had not been able to connect the reversal ratio with the problem solving principle. Students have not been careful in operating multiplication and division. This shows that there was procedural error caused because students did not understand the concept of multiplication and division of integers correctly as illustrated in the student's solution so that the final result obtained was wrong, namely $B_{2} 60=\frac{3800}{60}$ (YYA1HT04) then obtained the value $B_{2}=5100$ (YYA1HT06) . Furthermore, students have not been able to write conclusions correctly. This causes fact errors because students have not been able to connect what is being asked in the questions with what must be concluded as written by the student, namely the distance traveled is 5,1 cm (YYA1HT07).

b) Analysis of completion in question number 2

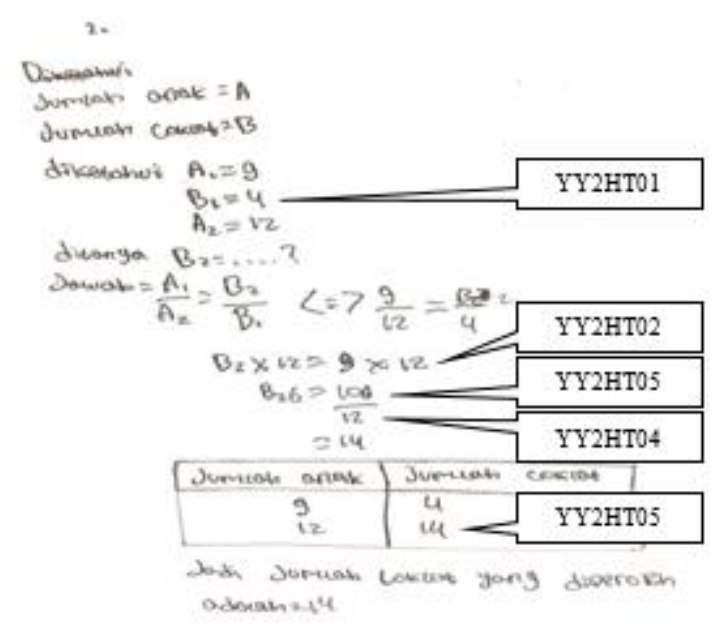

Figure 6. YYA students answers to question number 2

Based on the results of the student completion analysis, it is illustrated that students have not been careful in using units in writing the information contained in questions such as those in YYA2HT01. This causes factual errors because students have not been able to connect the information contained in the questions with those being asked. In addition, students have not been able to operate the reverse value comparison correctly as illustrated by the student's completion, namely $B_{2} \times 12=9 \times 12$ (YYA2HT02). This description shows a misconception caused by the fact that students have not been able to relate the formula for the comparison of the value to its solution. Furthermore, students have not been careful in writing down the information contained in the questions, namely when writing $B_{2} 6=\frac{108}{12}$ (YYA2HT03) while in the known section $A_{2}=12$. This description shows that there are fact errors caused because students are not careful in writing numbers correctly. Furthermore, students have not been careful in operationalizing the division of integers as illustrated in the student's solution, namely $B_{2} 6=\frac{108}{12}$ (YYA2HT04). This also led to procedural errors in the processing of student questions so that the final result obtained was wrong, namely $B_{2}=14$. Furthermore, students have not been able to write conclusions correctly. This causes fact errors because students have not been able to connect what is being asked in the questions with what must be concluded as written by the student, the number of chocolates obtained is 4 (YYA2HT05).

\section{Discussions}

Based on the results of the analysis of the student's problem solving, it was found that the errors made by the students in solving the comparison questions turned around, namely conceptual and procedural errors. Conceptual errors include errors in facts, concepts and principles. The types of conceptual errors include errors in facts, concepts and principles [11].

1) Fact Errors

Fact errors made by students consist of: a) errors in not writing the time and distance units. This error is illustrated in question number 1 , namely student $\mathrm{C}$ writes time $=1,2$ should time $=1.2$ hours, HD students write $a_{1} 1,2, b_{1} 80, a_{2}=60$ should be $a_{1} \quad 1,2$ hours, $a_{1} 1,2 \mathrm{jam}, b_{1} 80 \mathrm{~km} / \mathrm{hour}$ and $a_{2}=60$ minutes and YYA students write, and $B_{2}=80$ should be $B_{2}=80 \mathrm{~km}$ / hour. This error is a mistake of fact. This is in line with [6] which states that the mistakes made by students include incomplete writing what is known and asked about the questions. b) The error did not write the equal sign as depicted on the student's completion. In question number 1 student $C$ wrote $\frac{1,2}{80} \frac{b}{60}$ it should be $\frac{1,2}{80}=\frac{b}{60}$ and in question number 2 wrote $\frac{9}{4} \frac{a}{12}$, it should be $\frac{9}{4}=\frac{a}{12}$. HD students write $a_{1} 1,2$ and $b_{1} 80$ in question number 1 , it should be $a_{1}=1,2$ hours and $b_{1}=80 \mathrm{~km} /$ hour and number 2 , namely $a_{1} 9, b_{1} 4$, and $a_{2} 15$, it should be $a_{1}=9, b_{1}=4$, and $a_{2}=15$. This error is a mistake of fact. This is in line with previous research which states that factual errors are students' mistakes in understanding the agreements expressed through certain symbols or problems. Factual errors include the use of wrong terms, errors in defining, errors in notating and errors in giving symbols $[7,8]$. c) Writing errors that are known to be different from what HD students do in question number 2, namely HD students assume that many children $=b$ and the number of chocolates $=\mathrm{c}$, while writing what is known HD students do not use variables $b$ and $c$ but use $a$ and $b$. This error is a mistake of fact. Students have written what they know and 
ask but cannot continue to solve the next problem [9]. Writing is known but not in accordance with the questions they read. Based on the results of interviews with several students, it turned out that the students were still confused about what in the questions. When students already know what they are looking for in the questions, students are still confused about what method to use to solve the existing questions. d) Errors do not write conclusions and draw conclusions. The mistake of not writing the conclusion was made by student $\mathrm{C}$ on questions number 1 and 2 . The mistake of drawing conclusions was made by HD students on question number 1 by writing the average car was 64 . YYA students made a mistake in question number 1 , namely by writing the distance obtained each distance is $5.1 \mathrm{~km}$ and question number 2 is the number of chocolates obtained is 14.

\section{2) Concept Errors}

Misconceptions made by students consisted of: a) Errors in not being able to operate the reverse value comparison because they did not understand the concept of fraction comparisons as did student $\mathrm{C}$ in question number 1 , namely $\frac{1,2}{80}=\frac{b}{60} \leftrightarrow b \times 60=80 \times 1,2 \quad$ should be $\frac{1,2}{1}=\frac{b}{80} \leftrightarrow b \times 1=80 \times 1,2$.This error is a misconception. This is in line with the opinion of [10] which states that students do not master number operations, namely errors in placing multiplication and addition operations, students do not understand the essential concepts, meaning that students cannot work or solve problems completely. b) The error did not understand the concept of multiplying a decimal number with an integer like what HD students did in question number 1 , namely $b_{2} \times 15=80 \times 1,2$ and obtained $\quad b_{2} \times 15=960$. It should be $b_{2} \times 1=80 \times 1,2$ so that the value of $b_{2}=96$ is obtained. c) The error of not understanding the concept of division as done by YYA students in question number 1 , namely $\frac{3800}{60}=5100$ where YYA students cannot divide large numbers. This error is a misconception. The conceptual errors include errors in defining concepts, errors in distinguishing between examples and non-examples of a concept, providing illustrations that are not in accordance with the definition of the concept presented and presenting the relationship of two or more concepts or not being appropriate [8].

Procedural errors made by students consisted of: a) errors in determining the final result because there was an error in the work steps that were not complete. As was done by student $C$ in question number 1 , namely $b=1,6$, the value of $b_{2}=96 \mathrm{~km} /$ hour should be obtained and question number 2 , namely $a=27$, the value of $a_{2}=3$ chocolate candies should be obtained. This error is a procedural error. The errors in doing anything done by students are improper procedures so that there is confusion in student answers [11]. The incorrect procedure is caused by the subject lack of understanding of the principles of algebra operations, the error is indicated by students not using the right method so that there is confusion when working on the problem [12]. b) Errors in operating numbers like what HD students did in question number 1 , namely $b_{2} \times 15=80 \times 1,2$ then obtained $b_{2} \times 15=960$. It should be that $b_{2} \times 1=80 \times 1,2$ then the value of $b_{2}=96 \mathrm{~km} /$ hour is obtained. Errors in operating numbers were also made by YYA students in questions 1 and 2. The errors in question number 1 were $\frac{62}{60}=\frac{B_{2}}{80}$ then on the next line YYA students wrote $B_{2} \times 60=62 \times 60$. It should be $\frac{1,2}{1}=\frac{B_{2}}{80} \leftrightarrow B_{2} \times 1=1,2 \times 80$. The error in question number 2 is $\frac{9}{12}=\frac{B_{2}}{4}$ then on the next line YYA students write $B_{2} \times 60=62 \times 60$. It should be $\frac{1,2}{1}=\frac{B_{2}}{80} \leftrightarrow B_{2} \times 1=1,2 \times 80$. This error is a procedural error. In general all students are able to choose the correct procedure / steps, but during the calculation process students make mistakes, namely errors in the operations of addition, subtraction, multiplication and division [13]. This happens because students are not careful in counting. c) Errors in calculating multiplication and division as done by YYA students in questions number 1 and 2. The error in question number 1 is $B_{2} \times 60=62 \times 60$ then obtained $B_{2} 60=\frac{3800}{60}$ then the result is $B_{2}=5100$. It should be that $B_{2} \times 1=1,2 \times 80 \leftrightarrow B_{2}=\frac{96}{1}$ and the value of $B_{2}=96 \mathrm{~km} /$ hour is obtained. The error in question number 2 , namely $B_{2}=\frac{108}{12}$, then obtained $B_{2}=14$. It should be $B_{2}=\frac{36}{12}$ and you should get the value of $B_{2}=3$ chocolate candies. This error is a procedural error. The operating errors are student errors in performing arithmetic operations [7]. d) Errors in doing incomplete as was done by YYA students in questions number 1 and 2. YYA student's error in question number 1 was $\frac{3800}{60}=5100$ and the error in question number 2 was $\frac{108}{12}=14$. This error is a procedural error. The mistakes made by students are incorrect work procedures so that there is confusion on the steps of the process [14].

\section{Conclusion}

Based on the results of research and discussion, it can be concluded that the results of the analysis of students completion, namely the errors made by the students in solving the comparison of turning points were obtained. Conceptual errors include: a) factual errors consisting of: 1) students have not been able to write down the information contained in the questions, 2) students have not been able to 
understand the use of the equal sign correctly, 3) students have not been able to change the information contained in the questions into a model mathematics and 4) students have not been able to write conclusions correctly. b) Misconceptions consist of: 1) students do not understand the concept of reversing value comparisons, namely students working on comparison questions of turning values using the principle of value comparisons, 2) students have not been able to operate a reversed value comparison and 3) students do not understand the concept of multiplication and division of integers and decimal numbers. Procedural errors consist of: 1) students have not been able to work on questions using the principle of reversing value comparisons, 2) students make mistakes operating multiplication and division and 3) students have not been able to determine the final result correctly.

The factors that cause errors in problem solving of class VIIIF students of SMP Negeri 9 Palu in the comparison material are reversed in value, namely students are less in understanding the concept of comparison material, students are mistaken in solving comparative questions turning scores and lack of skills in solving questions.

\section{Acknowledgement}

I would like to express our gratitude to Rector Tadulako Universitas who gave us the support to do this research. Also, I would like to thank our friends in our university who helped us a lot in finalizing this research within the limited time frame. Thank you to SMP Negeri 9 Palu for allowing us to do this research.

\section{References}

1. Ruseffendi, E.T. (2006). Pengantar Kepada Membantu Guru Mengembangkan Kompetensinya dalam Pengajaran Matematika untuk Meningkatkan CBSA. Bandung: Tarsito

2. Hudojo, H. (2009). Belajar dan Mengajar Matematika. Malang: IKIP Malang.

3. Wijayanti, S. (2013). Pengaruh Pendekatan MEAs terhadap Kemampuan Pemecahan Masalah, Komunikasi Matematis, dan Kepercayaan Diri Siswa. PYTHAGORAS: Jurnal Pendidikan Matematika. Volume 8 No.2, pp. 181-192, Desember 2013.

4. Salle, N. \& Pai'pinan, M. (2016). Analisis Kesalahan Siswa dalam Menyelesaikan Soal Matematika pada Topik Keliling dan Luas Lingkaran di Kelas VIII C SMP YPK Hedam Semester Genap. Jurnal Ilmiah Matematika dan Pembelajarannya, 3(1), 23-30.

5. Sugiyono. (2014). Metode Penelitian Pendidikan Pendekatan Kuantitatif, Kualitatif, dan $R \& D$. Bandung: Alfabeta.
6. Nurussafa'at, F.A. (2016). Analisis Kesalahan dalam Menyelesaiakan Soal Cerita pada Materi Volume Prisma dengan Fong's Schematic Model for Error Analysis ditinjau dari Gaya Kognitif Siswa (Studi Kasus Siswa Kelas VIII Semester II SMP IT Ibnu Abbas Klaten Tahun Ajaran 20213/2014. Jurnal Eletronik Pembelajaran Matematika. Vol. 4 No. 2, pp. 174-187, April 2016.

7. Hidayat, B.R. (2013). Analisis Kesalahan Siswa Dalam Menyelesaikan Soal Pada Materi Ruang Dimensi Tiga Ditinjau Dari Gaya Kognitif Siswa (Penelitian Dilakukan di SMA Negeri 7 Surakarta Kelas X Tahun Ajaran 2011/2012). Jurnal Pendidikan Matetematika Solusi. Vol 1 No. 1 Maret 2013, pp. 39-46.

8. Hamid, A. (2013). Analisis Kekeliruan Pengungkapan Objek Matematika Siswa SMA di Kota Palu. Tesis. Pascasarjana Malang.

9. Anshori, M.T. (2018). "Analisis Kesalahan Siswa dalam Menyelesaikan Soal Cerita Perabandingan Berbalik Nilai di Kelas VII SMP”. Jurnal Pendidikan dan Pembelajaran Khatulistiwa. Vol 7 No. 1, 2018, pp. 77-78.

10. Bernard. Martin. (2018). Analaisi Kemampuan Pemecahan Masalah Matematis Siwa SMP Kelas IX pada Materi Bangun Datar. Supremum Journal of Mathematics Education (SJME). Vol.2 No.2, July 2018, pp. 77-83.

11. Ramlah, Bennu, S., \& Paloloang, B. (2016). Analisis Kesalahan Siswa dalam Menyelesaikan Soal Penjumlahan dan Pengurangan Pecahan di Kelas VII SMPN Model Terpadu Madani. Jurnal Ilmiah Pendidikan Matematika, 1(2), 182-194. doi:10.26877/jipmat.v1i2.1245

12. Huljannah, M. (2015). Analisis Kesalahan Siswa dalam Menyelesaikan Soal Persamaan dan Identitas Trigonometri Berdasarkan Kriteria Watson di Kelas X SMA Al-Azhar Palu. AKSIOMA Jurnal Pendidikan Matematika. Vol. 4 No. 02, 2015.

13. Islamiyah, Anna Citra. (2019), Analisis Kesalahan Siswa SMP pada Penyelesaian Masalah Sistem Persamaan Linear Dua Variabel. Jurnal Didaktik Matematika.

14. Febriani, E.D. (2018). Analisis Kesalahan Siswa dalam Menyelesaikan Soal Cerita Matematika Berdasarkan Analisis Kesalahan Newman pada Siswa Kelas VIII SMP Negeri 7 Padang. Jurnal Edukasi dan Penelitian Matematika. Vol 7 No. 4, 2018, pp. 24-29. 